\title{
The Effectiveness Of Paired-Share Gallery Walk (PSGW) On Students' Critical Appraisal Skill (CAS) Improvement During The Medical Surgical Nursing Clinical Placement
}

\author{
Andina Setyawati*, Moh Syafar Sangkala, Abdul Majid, Rini Rachmawaty \\ PSIK Universitas Hasanuddin, Jl. Perintis Kemerdekaan km.10, Kampus Tamalanrea, \\ Makassar, Sulawesi Selatan, 90245 \\ E-mail*: salsabila02@gmail.com
}

\begin{abstract}
Introductions: Less critical nurses in Indonesia may happen due to the lack of contribution of the nursing institutions in enhancing the critical thinking skill. The PSGW is one of clinical teaching methods that facilitates students to criticize the current literatures. This study aimed at identifying the effectiveness of the PSGW on students' critical appraisal skill (CAS) improvement during the medical surgical nursing clinical placement. Methods: This quasy-experimental study used pre-posttest control group design. The subjects were students who are currently in the professional practice stage of medical surgical nursing area. They were randomly assigned into two groups: 30 subjects in intervention group who conducted PSGW and 30 subjects in control group who conducted standard method of journal presentation. CAS questionnaires developed by Oxford University had been used to measure students' CAS in criticizing the journal. The data was analyzed using Wilcoxon, Mann-Whitney, paired $t$-test, and independent $t$-test with level of significance at 0.05.Results: The intervention group experienced a significant increase in CAS score $(p=0.0001)$ after performing the PSGW, while the control group experienced an insignificant decrease $(p=0.596)$ after performing the standard method of journal reading. When comparing the posttest CAS of both groups, the result showed that there were significant differences in the posttest CAS scores ( $p=0.0001)$ with large effect size $(r=0.63)$. Conclusions: The PSGW is an effective learning method for clinical teaching. Further study needs to be performed to investigate the effectiveness of PSGW on the academic learning process.
\end{abstract}

Keywords : Paired-share gallery walk, critical appraisal skill, clinical students

\section{INTRODUCTION}

Cases on medical surgical nursing vary from simple cases to complex cases, so requiring the resources of nurses who are able to critically think.Critical thinking is related to decision making process and clinical assessment so it can be used as a determinant whether the quality of nursing care is good or not. Aprisunandi (2011)in his study of 45 nurses in the orthopedic room found that there was a significant relationship between nurses' critical thinking with nursing care quality. Nurses who were critically think have six times the chance to perform good quality nursing care.

Brunt (2005)suggests the same thing that critical thinking is needed to address increasingly complex health problem. Critical thinking is a lifelong process that involves selfawareness, knowledge and practice which reguires critical spirit. The spirit needs to be nurtured since studying in higher education, so it is become the educational institution's obligation to create a culture of critical thinking.
Indonesian nurses tend to perform their duties without updating their knowledge about the current best practice of nursing care. Mulyaningsih (2013)on her study among 99 nurses, found that $76 \%$ nurses still need coaches in critical thinking. Her study also found that there is a positive relationship between nurses' critical thinking ability and caring behavioral improvement.

School of nursing, Hasanuddin university, has performed students' critical thinking learning, one of them is on the medical surgical nursing profession stage with journal reading assignment. The journal is assigned as a rational of nursing intervention, which will be assessed by discussion beetwen preceptor and preceptee. The assignment of this journal began to be evaluated by advance presentation in front of the class with power point media by 2015/2016 (Departemen KMB UNHAS, 2016).

Survey on May, 2017 to 71 students of medical surgical nursing profession stage of Hasanuddin University, showed that $95.77 \%$ of students do not know ho to critizise article, 
while survey to 6 students of critical care nursing stage showed that, $83.33 \%$ of students do not know how to critizise journal according to golden standar of a kind of research. Similarly, Azizi-Fini, Hajibagheri and AdibHajbaghery (2015) study of 150 nursing students found that the new students' low critical thinking had no significant differences compared with their final semester students'.

Critical appraisal skill (CAS) which assessed by journal presentation method is expected to improve the quality of nursing care(Tingen et al., 2009). Presentation by students is one of the active learning method that can be applied to nursing education and journal reading itself is a trigger instrument for students to learn critical thinking (Xu, 2016).However, the survey by the medical surgical nursing team atschool of nursing, Hasanuddin University, in 2016, found that presentation with 5-6 students in a group is only $10-20 \%$ who understand well the contents of 'within' group journal and $15-20 \%$ who understand well the content of 'between' group journal.

Because the importance of an educational method to achieve a good final evaluation result (Stravopoulou\&Kelesi, 2012), so in the even semester of academic year 2016/2017 the team innovate on the method of journal presentation by using paired-share gallery walk (PSGW) which is gallery walk with one stay one stray.The implementation of gallery walk withvarious design has been showed to improve learning achievement(Pandapotan, 2016), improve communication skill (Bowman, 2005) and improve relationship among learners(Ganeshini, 2014). Gallery walk is also a collaborative learning that is considered the learners to be the most interesting method that motivates to do further discussion so that gallery looks attractive and perfect, where willingness to study will further learn the ability of critical thinking(Thayer-Bacon, 2000).

A qualitative study on 7 participants gallery walk of musculoskeletal system learning by the year 2016/2017 school of nursing Hasanuddin University, found that gallery walk is able to make students to understand the content of the literature by reading other comparative literature to understand completely. This is mainly because participants are challenged do display and explain perfectly the material of their gallery.
The experiment study in this musculoskeletal lesson also found that one stay one straygallery walk method which referred to PSGW was found to be more effective than other designs of gallery walk.83\% PSGW participants understand the content of entire gallery material while $34 \%$ participants of other designs gallery walk who understand the content of entire gallery material (Setyawatiet $a l, 2016)$. So, it is expected that the students' critical thinking in the learning stage of profession will increase through PSGW, especially in critiquing the contents of articles in journals.

\section{METHODS}

This research was an experiment study with pre-post test with control group design. The study was conducted at nursing department, Hasanuddin University. The population of this study were all students of medical surgical nursing stage part 1 and 2, in the beginning semester of academic year 2016/2017 in totaling 71 students. Informed consent is done first. Ethical clearance has been issued from the ethical committee, Medical Faculty, Hasanuddin University.

Samples were taken by quota random sampling, divided into intervention group and control group. The sample of each group was 30 subjects taken from three cycles periods, These number of subjects was obtained according to the inclusion criteria : 1)willing to be a subject; 2)present at the program presentation; 3)follow the rules, while the exclusion criteria: 1) on leave; 2)coming late.

Independent variable of this study ispaired-share gallery walk (PSGW).PSGW was implemented in the fourth week of each cycle in both group, intervention and control group. PSGW is an exposure journal method with one stay one stray design consists of two session where students previously assigned indovodual tasks searching for randomized controlled trial (RCT) journal as a rational of one nursing intervention of their case and present using gallery they made by themselves. PSGW performed in classroom with the following step :

1) Reflection of PSGW step and contract time. 


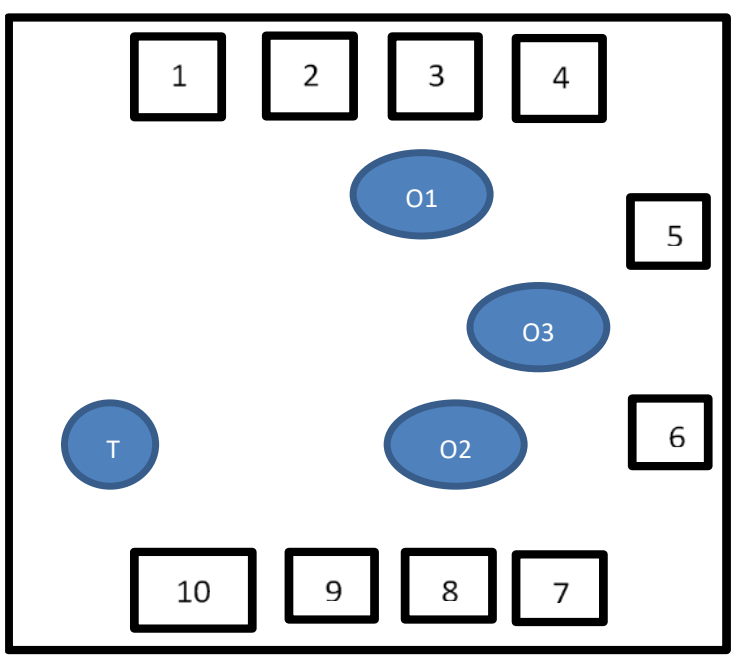

Picture 1. Room Setting

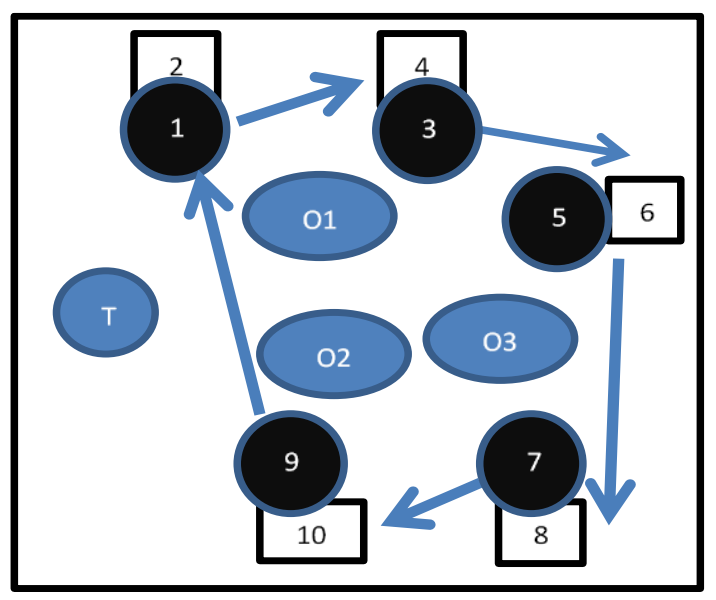

Picture 3. Session 2 activities of $P S G W$

2) Researches divide the chest number(no. 110 for cycle 1 , no. 11-18 for cycle 2 and no 19-30 for cycle 3 ).

3) Setting the room and the preparation along with the subjects, determine the position and attach the gallery on the walls. Illustration of picture 1 below as an example of PSGW session 1, as you can see in picture 1.

4) Assessor preparation (Assessed by subjects), each subjects (stray) assess the presenter and gallery performance (stay), the value is written on a blank sheet of paper available in the range $0-100$. The paper will be collected in the end of the session, the assessor at session one is the subject with the even chest number while the assessor at session two is the subject with odd chest number.

5) Session one activities are as follows :

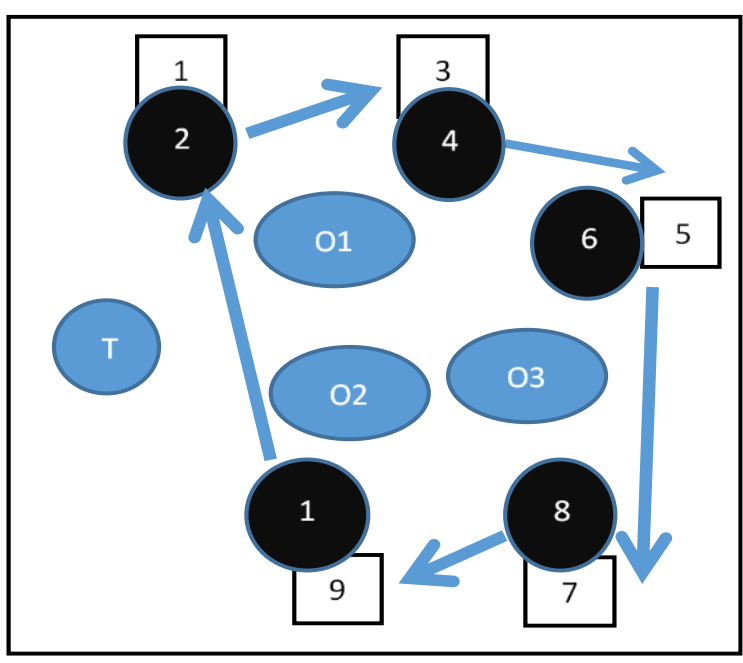

Picture 2. Session 1 activities of PSGW

\section{Note:}

The squares show the subjects' chest number.

$\mathrm{T}$ in blue circle as a symbol of timer.

The O1-O2-O3 in blue ovale as symbols of observers.

The number in black circles are the direction of the flow.

a) Subjects with odd chest number stay on their gallery to present the journal during 15 minutes to each stray.

b) Subjects with the even chest number walk around the gallery (clock wise) as a stray.

The numbers in squares show the subjects who are staying, the numbers in black circles showthe subjects who are straying, $\mathrm{T}$ in blue circle as a symbol of timer, O1-O2-O3 in blue ovales as symbols of observer, while blue arrows as symbols of strays' rotation direction, as you can see in picture 2 .

6) Session two activities are as follows :

a) Subjects with even chest number stay on their gallery to present the journal during 15 minutes to each stray. 
b) Subjects with the odd chest number walk around the gallery (clock wise) as a stray.

The numbers in squares show the subjects who are staying, the numbers in black circles show the subjects who are straying, $\mathrm{T}$ in blue circle as a symbol of timer, O1-O2-O3 in blue ovales as symbols of observer, while blue arrows as symbols of strays' rotation direction, as you can see in picture 3.

7) Feedback, strengthening and evaluation.

8) Awarding 1 copy of ICON journal for the best presenter.

Control group performed standard presentation by using discussion panel method and power point as media to present their journal in front of the class.

Dependent variable in this study isCritical Appraisal Skill (CAS) which describes subjects' critical thinking ability in critiquing their journal, measured with modified 11-items of CAS questionnaire developed by Oxford University, which was divided by researcher into 18 questions consist of 11 questions to assess validity critiquing ability, 4 questions to assessimportancy critiquing ability and 3 questions to assess applicability critiquing ability. This CASP appraisal checklist downloaded from https://casp-uk.net/casp-tools-checklists/.

These are free to download and can be used by anyone under creative commons license.

The assessment used by score number, score 1 if subjects can not answer, score 2 if subjects answer uncertainly and score 3 if subjects answer perfectly. CASP is part of the Better Value Health Care (BVHC), a company belonging to Oxford University.BVHC has the function of creating and disseminating the result of health training for the benefit of the quality of health services.

Data were analyzed by using Wilcoxon Sign Rank Test to identify the differences in pre and post CAS score on intervention group, while Paired Samples Test was used on control group.Independent T-Test was used to compare CAS score pre between groups, while MannWhytney was used to compare CAS score post between groups.

\section{RESULTS}

Data collection in this study lasted for 12 weeks. The subjects were 60 students who are currently in the professional practice stage of medical surgical nursing area part 1 and 2 in the period ofMay 15 to August 19, 2017 which is divided into three cycles.30 Odd group students of part 1 i.e group $1 \mathrm{~A}, 3 \mathrm{~A}, 1 \mathrm{~B}, 3 \mathrm{~B}, 1 \mathrm{C}$ and $3 \mathrm{C}$ allocated as intervention group, wahile 30 even group students part 2 i.e $2 \mathrm{~A}, 4 \mathrm{~A}, 2 \mathrm{~B}, 4 \mathrm{~B}, 2 \mathrm{C}$ and $4 \mathrm{C}$ allocated as control group.

Both group were assigned the task of searching and critiquing the current journal as a rational one of nursing intervention with the guidance from preceptor since the second week of each cycle.In the fourth week of each cycle, the intervention group performed PSGW while control group performed standard presentation by using power point as media to present their journal in front of the class.In the end of this study, 60 were taken from 71 population 5intervention subject candidats were excluded because three of them were come late and two of them did not do their gallery, while 6 control subject candidats were excluded because they did not come to the presentation day.

Table 1.Subjects' characteristics $\left(n_{1}=n_{2}=30\right)$

\begin{tabular}{|c|c|c|c|c|c|}
\hline \multirow[t]{2}{*}{ Var } & \multicolumn{2}{|c|}{$\begin{array}{c}\text { Interventio } \\
\mathrm{n}\end{array}$} & \multicolumn{2}{|c|}{ Control } & \multirow[t]{2}{*}{$P v$} \\
\hline & $\mathrm{n}$ & $\%$ & $\mathrm{n}$ & $\%$ & \\
\hline Sex & & & & & 1.000 \\
\hline Man & 2 & 6.67 & 2 & 6.67 & \\
\hline Woman & 28 & 93.33 & 28 & 93.33 & \\
\hline G.P.A & & & & & 0.061 \\
\hline$>3.50$ & 15 & 50 & 23 & 76.67 & \\
\hline $3.00-3.50$ & 15 & 50 & 7 & 23.33 & \\
\hline Method & & & & & 1.000 \\
\hline interest & 25 & 83.33 & 24 & 80 & \\
\hline $\begin{array}{l}\text { Active L } \\
\text { Passive L }\end{array}$ & 5 & 16.67 & 6 & 20 & \\
\hline Task interest & & & & & 0.863 \\
\hline Individual & 12 & 40 & 10 & 33.33 & \\
\hline Small group & 16 & 53.33 & 20 & 66.67 & \\
\hline Large group & 2 & 6.67 & 0 & 0 & \\
\hline Journal & & & & & 0.107 \\
\hline $\begin{array}{l}\text { Reading } \\
\text { motivation }\end{array}$ & 8 & 26.67 & 3 & 10 & \\
\hline Less M & 22 & 73.33 & 25 & 83.3 & \\
\hline $\begin{array}{l}\text { Enough M } \\
\text { Very M }\end{array}$ & 0 & 0 & 2 & 6.67 & \\
\hline $\begin{array}{l}\text { Presentation } \\
\text { interest }\end{array}$ & & & & & 0.006 \\
\hline Standard (ppt) & 7 & 23.33 & 17 & 56.67 & \\
\hline Gallery/poster & 23 & 76.67 & 11 & 36.66 & \\
\hline Etc & 0 & 0 & 2 & 6.67 & \\
\hline
\end{tabular}


Table 2. CAS scores subjects' distribution $\left(n_{1}=n_{2}=30\right)$

\begin{tabular}{lccccc}
\hline \multicolumn{1}{c}{ Var } & Mean & SD & \multicolumn{3}{c}{ Skewness } \\
\cline { 4 - 6 } & & & Stat & SE & $P v$ \\
\hline Intervention & & & & & \\
CAS score & & & & & -0.60 \\
$\quad$ Before & 33.57 & 6.68 & -0.258 & 0.427 & -3.27 \\
$\quad$ After & 41.53 & 6.20 & -1.395 & 0.427 & \\
\hline Control CAS & & & & & -0.68 \\
score & & & & & 0.49 \\
$\quad$ Before & 36.37 & 4.16 & -0.290 & 0.427 & 0.427 \\
$\quad$ After & 36.03 & 5.19 & 0.211 & & \\
\hline
\end{tabular}

Table 3.Wilcoxon sign rank test of differences between CAS scores before and after PSGW in the intervention group $(n=30)$

\begin{tabular}{lcccccc}
\hline \multicolumn{1}{c}{ Var } & Q1 & Q2 & Q3 & $Z$ & $P v$ & 0.0001 \\
\hline CAS score & & & & -4.180 & & \\
Before & & & & & & \\
After & 28.7 & 34 & 39 & & & \\
& 5 & 42.5 & 46 & & & \\
& 38.7 & & & & & \\
& 5 & & & & & \\
& & & &
\end{tabular}

Table 4. Paired samples test of differences between CAS scores before and after Standard presentation in the control group $(n=30)$

\begin{tabular}{ccccccc}
\hline Var & $\begin{array}{c}\text { Mean } \\
\text { Diff }\end{array}$ & SD & SE & df & $P v$ & $95 \% \mathrm{CI}$ \\
\hline $\begin{array}{l}\text { CAS } \\
\text { score }\end{array}$ & 0.33 & 3.41 & 0.62 & 29 & 0.596 & $-0.94-1.606$ \\
\hline
\end{tabular}

Table 5. Differences CAS score before and after intervention between groups $\left(\mathbf{n}_{1}=\mathbf{n}_{2}=30\right)$

\begin{tabular}{|c|c|c|c|c|c|}
\hline Var & Mean & $S D$ & Mean Diff & $95 \% \mathrm{CI}$ & $P v$ \\
\hline *CAS & & & -2.8 & $-5.67-0.078$ & 0.056 \\
\hline score & & & & & \\
\hline before & 33.57 & 6.68 & & & \\
\hline $\begin{array}{l}\text { Interventio } \\
n\end{array}$ & 36.37 & 4.16 & & & \\
\hline Control & & & & & \\
\hline Var & Median & $\mathrm{U}$ & $\mathrm{Z}$ & $r$ & $P v$ \\
\hline $\begin{array}{l}* * \text { CAS } \\
\text { score after }\end{array}$ & & 196500 & -3.75 & 0.68 & 0.0001 \\
\hline $\begin{array}{l}\text { Interventio } \\
\mathrm{n} \\
\text { Control }\end{array}$ & $\begin{array}{c}42.5 \\
35.00\end{array}$ & & & & \\
\hline
\end{tabular}


Chi-square analysis in table 1 showed that between the two groups there was no significant difference in sex distribution $(\mathrm{p}=1.000)$, academic G.P.A ( $\mathrm{p}=0.061)$,interest in the type of learning method $(\mathrm{p}=1.000)$, interest in the form of assignment (0.863) andmotivation to read the journal $(p=0.107)$. the univariat test showed that the majority of gender in both group were female, with the major academic G.P.A of $>3.50$, smost subjects interested in active learning method with the assignment in small group, where members consist of 2-3 people in a group, as well as most subjects have enough motivation to read journal.

In contrast, there was a significant difference in interest of journal presentation method in both groups $(\mathrm{p}=0.006)$.Univariate test showed that the intervention group has more subjects who were interested in gallery/poster assignment than control group.

Table 2 showed the meanCAS scores before presentation of intervention group was lower than control group, i.e 33,57with 6.68standar deviation. Nevertheless, the mean CAS scores after presentation of the intervention grous was higher than the control group, i.e 41.53 with 6.20 deviation standard.

Table 2 also showed that CAS score before PSGW of the intervention group is normally distributed with skewness value-0.60, while CAS score after PSGW is not normally distributed with skewness score -3.27 . Normality test in control group showed that CAS score before and after standard presentation are both normally distributed with skewness values -0.68 and 0.49 .

Table 3 showed that there was a significant CAS score increase after PSGW in intervention group, $\mathrm{z}=-4.18, \quad p<0.005$ with medium effect size $(\mathrm{r}=0.30)$. The median scores showed that the value before PSGW $(\mathrm{Md}=34)$ increased after PSGW (Md=42.5).

Table 4 showed that there was an insignificant decrease of CAS score after standard presentation in control group, with a score CAS before standard presentation $(M=36.37, \mathrm{SD}=4.16)$ decresed after standard presentation $(M=36.03, \mathrm{SD}=5.19), \mathrm{t}(29)=0.54$, p> 0.005 (two-tailed). The score mean was reduced by 0.33 in the range of -0.94 to 1.61 with confidence interval $95 \%$.

Table 5 showed that there was an insignificant differences of CAS score before between intervention $(M=33.57, \mathrm{SD}=6.68)$ and control group $(M=36.37, \mathrm{SD}=4.16) ; \mathrm{t}(58)=-$ $1.95, p=0.056$ (two-tailed), while there was a significant differences of CAS score after between intervention group $(M d=42.5, n=30)$ and control group with large effect size $(M d=35.00, \quad n=30), \quad \mathrm{U}=196500, \quad \mathrm{z}=-3.75$, $p=0.0001, \mathrm{r}=0.68$.

\section{DISCUSSIONS}

One of the essensial goals of nursing education is to produce nurses who are able to maintain and improve the outcome of nursing care.Therefore, educators need to transfer their knowledge expertise in accordance with actual field condition which require the proper instructional design (Su \&Osisek, 2011). The purpose of education in Indonesia both academic and profession stage refers to the framework of Indonesian national qualifications (KKNI) in accordance with the Indonesia Republic's law (UU RI) No.20 of 2003. UU RI No.38 of 2014 mentioned that nursing education should refers to these KKNI, where a nurse must have a level 6 cognitive that is up to the evaluation stage in accordance with Bloom's taxonomy.

Paired-share gallery walk (PSGW)is applied as a journal presentation method to achieve the competence of professional nurses which designed according to Bloom's taxonomy, including aim to hone cognitive ability of higher order thinking skill, i.e level 4 (analyze), level 5 (evaluation) and level 6 (sintesys). In addition, also to hone the affective skills up tolevel 5 (controlling behaviour) and to hone psychomotor skills up to level 4 (natural reaction) (Iowa State University, 2016).

The assignment of journal searching and analyzing in this study is one of the activities to support the continuing nursing education by cultivating nurses searching for evidence-base to be used as rationale of nursing intervention as part of nursing care of their cases.PSGW is an evidence-base delivery method in which the students' critical thinking is stimulated by repetition delivery that fascilitates discussion with many people.

This study found that there was a significant increase of CAS score before and after PSGW in intervention group ( $\mathrm{p}=0.0001)$, but there was an insignificant decrease of CAS score before and after standard presentation in control group $(\mathrm{p}=0.056)$. Further analysis 
showed that there was a significant differences of CAS score after presentation between intervention and control group (0.0001) in which PSGW gave large effect of increasing the CAS score of learners $(\mathrm{r}=0.68)$.

Subjects in this study were given individual assignment to create a gallery from an experimental research journal with randomized clinical trial design, which should at least contain: problem, intervention, comparison, outcome and time. CAS is a thorough and systematic review process that is essential to take a decision wheter the result of the research can be applied in a health care setting(Kumar et al., 2009).

Experimental study is the lowest biased level of research, however experimental study may be inaccurate if the research method is not appropriate, so in this PSGW the subjects are stimulated to discuss the question s contained in CAS questionnaire, which refers to the consolidated esperimental research resporting standard known as the consolidated standards of reporting trials (CONSORT) 2010. CONSORT makes it easier to report every experimental research result with a methodology that can improve the quality of its result(Schulz et al., 2010).

Univariate analysis per CAS item where there are 18 modified items from 11CASP items in this study, showedan increase in the mean score of all CAS items after PSGW in the average range increased by 6.9 to 44.8 on the component of the ability to analyze the validity, 13.8 to 69 on the component of the ability to analyze importancy and 10.3 to 31.1 on the component of the ability to analyze applicability. The double blind item is the lowest increase by 6.9 , the majority of subjects did not understand the meaning of double blind. The minority subjects who answered this item correctly in the post test is a subject who actively asking question as a stray and actively stimulate the strays as a speaker.Researchers as observers also play a role in transferring knowledge and aligning inappropriate opinions during PSGW process.

The researchers in this study have experience in managing PSGW in academic process three times. The study of Rodenbaugh (2015)found that the experience of lecturers to manage peer-assessed gallery walk with the concept of one teaching one learneris related to the improvement of communication skill and express opinions of the lecture and also students. The challenges of implementing this gallery walk is to anticipate the chaos and good time management.

Two subjects of intervention group did not experience an increase of CAS score after PSGW. Their score are the same before and after intervention.Further analysis, both subjects are interested in passive learning method, small group assignment and interested present their journal with standard method through power point presentation, although they are motivated to read a journal. The academic G.P.A of this subjects is in the range of 3.00-3.50 where Hasanuddin university school of nursing's learning has been using active learning.Based on observation, both subjects were passive during the PSGW process.This is in accordance with study ofWasti (2013)that interest in learning methodrelated to seriousness in learning process and improvement of learning result.

This research also reports that six subjects of control group experience in increase of CAS score after performing standard method, where as they are interested in passive learning methods and are interested performing standard method to present their journal.The selection of learning methods is often not in accordance with students interest, but in accordance of teaching material. Graaf., et al (2015) mentioned thatthe students interest is not the main thing to consider the method of learning, but the teaching material.So this is the lecturer's duty to make students interested in the learning method.

PSGW can be applied to the evidencebased assignment of nursing students in managing individual cases, thereby having the major impact on improving students' critical thinking skills in choosing nursing intervention in accordance with established nursing diagnoses. This rational of interventions using this evidence-base require critical thinking to mastery of concept on high cognitive level indicators i.e $\mathrm{C} 4, \mathrm{C} 5, \mathrm{C} 6$ of Bloom's taxonomy (Xu, 2016).

The use of gallery walk method with two stay two stray gave big impact on mastery of concept, while the use of gallery walk with two stay small group stray gave medium impact and the use of gallery walk with two stay big group stray gave no impact on of concept (Mohammadi.,et al, 2017). So smaller the stray, the more effective gallery walk. This effectiveness is proven again with the 
application of one stay one stray gallery walk in this study. The concept of one stay one stray on PSGW is aimed at establishing students in handling their patients. This PSGW takes a long time in each sintax so it needs to be designed to match the time so that proper time allocated.

Repetition are also part of the PSGW process. The result of subjects evaluation found that explain the material 4-6 times made them understand the article concept, while being stray made them expand their knowledge.Augustin (2014) wrote in his review that thetesting effect,active recall dan spaced repetition are practical learning strategy to learn effectively and overcome retention in factual knowledge.In pSGW, students visualize the article in the form of drawings and flow charts that are easy to understand and draw with manipulations of various colors and shapes. So with PSGW, students are faced with relaxed classroom atmosphere, where this method psychologically reduces the stress(Tan and Alcantara., 2017)in learning evidence-base which is a daunting task from the point of view of nursing students.In fact, the majority of nurses still have very low knowledge about concept of evidence-base practice. Basically, the nurses do not have enough preparation in terms of knowledge and habits and doing research and read the recent article that is very important in the nursing implementation (Ligita, 2012).

PSGW as one of the innovative gallery walk learning method with one stay one stray design can be used to enrich the learning method both in academic and profession stage, especially for an evidence-base assignment to learn critical thinking skills. Thus, Indonesian nursing education institutions will contribute to the improvement of nursing care quality by Indonesian nurses.

The limitation, this study did not test the validity and reliability since the checklist was translated into Indonesia language.

\section{CONCLUSSIONS}

PSGW with the concept of one stay one stray used to improve critical appraisal skill of profession stage students, specially surgical medical nursing placement. PSGW also can be applied to all students of nursing profession.Further researched need to investigate PSGW application with the same concept by comparing its application at the beginning semester until the end of semester.

\section{REFERENCES}

Aprisunandi (2011) Hubungan Antara Berpikir Kritis Perawat dengan Kualitas Asuhan Keperawatan di Unit Perawatan Ortopedi Rumah Sakit Umum Pusat Fatmawati Jakarta, Tesis. Universitas Indonesia.

Augustin, M. (2014) 'How to learn effectively in medical school: Test yourself, learn actively, and repeat in intervals', Yale Journal of Biology and Medicine, 87(2), pp. 207-212.

Azizi-Fini, I., Hajibagheri, A. and AdibHajbaghery, M. (2015) 'Critical Thinking Skills in Nursing Students: a Comparison Between Freshmen and Senior Students', Nursing and Midwifery Studies, 4(1). doi: 10.17795/nmsjournal25721.

Bowman, S. L. (2005) The Gallery Walk: An Opening, Closing, Review Activity. Glenbrook.

Brunt, B. A. (2005) 'Critical thinking in nursing: An integrated review', The Journal of Continuing Education in Nursing, 36(2), pp. 60-67. doi: 10.1097/00003465-199511000-00006.

Chin, C.K., Aquino, J.B., and Kian, T.T. (November, 2016). Peer-asseesed gallery walk as a teaching strategy: a professional development experience for $21^{\text {st }}$ century education. Third International Conference on Teacher Learning and Development, Penang, Malaysia.https://www.researchgate.net/p ublication/311984269_Peer-

Assessed_Gallery_Walk_as_a_Teaching _Strategy_A_Professional_Development _Experience_for_21st_Century_Educati on_Peer-

Assessed_Gallery_Walk_as_a_Teaching _Strategy_A_Professional_Development _Experiendiakses tanggal 12 September 2017.

Critical Appraisal Skill Programme. (2017). CASP randomized controlled trial checklist.http://www.casp-uk.net.

Diakses pada tanggal 20 April 2017.

Departemen KMB UNHAS (2016) Surgical Medical Nursing Professional 
Handbook. Universitas Hasanuddin.

Ganeshini (2014) Strengthening student engagement in the classroom.

Graaf, E and Farreras, M. (2015). Active teachers active students. $13^{\text {th }}$ International Workshop Active Learning in Engineering, Spain. pure.au.dk/portal/files/96597406/ALE_2 015_proceedings_final.pdfdiakses pada tanggal 12 September 2017.

Kumar, A. et al. (2009) 'Critical appraisal skills are essential to informed decisionmaking', Indian Journal of Sexually Transmitted Diseases and AIDS, 30(2), p. 112. doi: 10.4103/0253-7184.62770.

Ligita, T. (2012) 'Pengetahuan , Sikap dan Kesiapan Perawat Klinisi dalam Implementasi Evidence-Base Practice', NERS Jurnal Keperawatan, 8(1), pp. 83-85.

Mohammadi, I., Taghinejad, H., Suhrabi, Z., and Tavan, H. (june, 2017). The correlation of various method gallery walk and academic learning achievement of nursing students. Journal of Basic Research in Medical Science, 4(3) : 8-13.

Mulyaningsih (2013) 'Peningkatan Perilaku Caring Melalui Kemampuan Berpikir Kritis Perawat', Jurnal Managemen Keperawatan, 1(2), pp. 100-106.

Pallant, Julie. (2011). SPSS survival manual :a step by step guide to data analysis using $S P S S, 4^{\text {th }} E d$. Australia : Allen \& Unwin.

Pandapotan (2016) Penerapan Strategi pembelajaran Gallery Walk untuk Meningkatkan Hasil Belajar Siswa pada Mata Pelajaran Ilmu Pengetahuan Sosial. Universitas Islam Negeri Sultan
Syarif Kasim Riau.

Rodenbaugh, D. W. (2015) 'Maximize a teambased learning gallery walk experience: herding cats is easier than you think', Advances in Physiology Education, 39(4), pp. 411-413. doi: 10.1152/advan.00012.2015.

Schulz, K. F. et al. (2010) 'CONSORT 2010 statement: updated guidelines for reporting parallel group randomised trials.', BMJ (Clinical research ed.), 340(mar23 1), p. c332. doi: 10.1136/bmj.c332.

Tan, C. and Alcantara., M. C. (2017) 'Gallery Walk Technique in Teaching Selected Topics in English and Learners' Performance.', International Journal of Advanced Research, pp. 1000-1002. doi: 10.21474/IJAR01/3598.

Thayer-Bacon, B. (2000) 'Transforming Critical Thinking: Thinking Constructively', Studies in Philosophy and Education, 22, pp. 123-148. doi: 08077-3924-3.

Tingen, M. S. et al. (2009) 'The importance of nursing research.', The Journal of nursing education, 48(3), pp. 167-70. doi: 10.3928/01484834-20090301-10.

Wasti, S. (2013) 'Hubungan Minat Belajar Dengan Hasil Belajar Mata Pelajaran Tata Busana Di Madrasah Aliyah Negeri 2 Padang', E-Journal Home Economic and Tourism, 2(1).

$\mathrm{Xu}, \mathrm{J}$. (2016) 'Toolbox of teaching strategies in nurse education', Chinese Nursing Research, 3(2), pp. 54-57. doi: 10.1016/j.cnre.2016.06.002. 